\title{
ADAPTATION OF THE ACTIVATED SLUDGE TO THE DIGESTATE LIQUORS DURING THE NITRIFICATION AND DENITRIFICATION PROCESSES
}

\author{
Joanna Majtacz ${ }^{1 *}$, Przemyslaw Kowal' ${ }^{1}$ Xi Lu ${ }^{1,2}$, Hussein Al-Hazmi' ${ }^{1}$ Jacek Mąkinia ${ }^{1}$ \\ 1 Faculty of Civil and Environmental Engineering, Gdansk University of Technology, ul. Narutowicza 11/12, \\ 80-233, Gdansk, Poland \\ 2 Institute of Environmental Science and Engineering, Tongji University, 1239 Siping Road, Shanghai, \\ 200092, China \\ * Corresponding author's e-mail: joamajta@pg.gda.pl
}

Received: 2017.06.23

Accepted: 2017.08.01

Published: 2017.09.01

\begin{abstract}
The activated sludge process of the digestate liquors after chemical separation was conducted using a $10 \mathrm{~L}$ lab-scale sequencing batch reactor (SBR) and a $0.50 \mathrm{~m}^{3}$ pilotscale SBR independently (with $\mathrm{pH}$ control). Due to the relatively high concentration of free ammonia (FA), clear inhibitory effects of the digestate liquors on the nitrifying bacteria were observed. The adaptation of the activated sludge to the toxicity was evaluated with the trends of ammonia uptake rate (AUR) and nitrate utilization rate (NUR). The lab-scale AUR values decreased from 5.3 to $2.6 \mathrm{~g} \mathrm{~N} /(\mathrm{kg} \mathrm{VSS} \cdot \mathrm{h})$ over time after the addition of digestate liquors (5-10\% of the reactor working volume), indicating an apparent FA inhibition on the nitrification process in the FA concentration range of $0.3-0.5 \mathrm{mg} \mathrm{N} / \mathrm{L}$. The pilot-scale AUR values increased from 1.8 to $3.6 \mathrm{~g} \mathrm{~N} /$ $(\mathrm{kg} \mathrm{VSS} \cdot \mathrm{h})$ in the first two weeks and then decreased to $2.4 \mathrm{~g} \mathrm{~N} /(\mathrm{kg} \mathrm{VSS} \cdot \mathrm{h})$, showing a lag of the inhibition on the nitrifying bacteria at the FA concentration $\approx 0.15 \mathrm{mg} \mathrm{N} / \mathrm{L}$. The lab-scale NURs increased from 2.6 to $10.4 \mathrm{~g} \mathrm{~N} /(\mathrm{kg} \mathrm{VSS} \cdot \mathrm{h})$ over time, and the pilot-scale NURs increased from 1.0 to $4.0 \mathrm{~g} \mathrm{~N} /(\mathrm{kg} \mathrm{VSS} \cdot \mathrm{h})$ in a similar pattern. The clear dependence of both the lab- and pilot-scale NURs on time indicated the adaptation of the heterotrophic biomass to the digestate liquors. Ethanol - used instead of fusel oil - was found to be a more efficient external carbon source for better adaptation of the activated sludge under unfavorable conditions.
\end{abstract}

Keywords: digestate liquors; activated sludge; free ammonia; adaptation; inhibition

\section{INTRODUCTION}

Digestate liquors produced from the anaerobic digestion process could be considered as both a problematic medium as well as a valuable resource. Improperly treated digestate liquors may lead to serious environmental threats, such us emissions of greenhouse gases (GHG) and leaching of nutrients and organic matter to the natural environment (Holm-Nielsen et al., 2009). On the other hand, digestate liquors are also a valuable source of nitrogen and phosphorus compounds (e.g. ammonium $\left(\mathrm{NH}_{4}^{+}\right)$with the concentrations higher than $1000 \mathrm{~g} \mathrm{~N} / \mathrm{m}^{3}$ ) due to the hydrolysis and fermentation of the nitrogen and phosphorus fractions of the slowly biodegradable substrates (Onay and Pohland, 1998).

With regard to the treatment of digestate liquors, nutrients in the colloidal and suspended forms could be removed through a wide range of the physical and chemical separation methods, such as centrifugation, coagulation and floatation (Møller et al., 2006). The dried products could be further refined into concentrated fertilizers or fiber products (Holm-Nielsen et al., 2009). However, a substantial amount of dissolved nutrients still remains in the digestate liquors and may potentially cause eutrophication. In order to remove the dissolved nutrients from the digestate liquors, biological processes are considered, among 
which the activated sludge process is regarded as a promising alternative due to the ease of maintenance and high economic efficiency. Furthermore, the nutrients concentrated and deposited in the biomass could be subsequently processed for recovery (Daigger, 2014).

However, one of the most challenging issues for the pre-treatment of the ammonium-rich anaerobic sludge digestate liquors is the adaptation of the nitrifying bacteria to the high free ammonia (FA) concentration. Similarly to the landfill leachate, digestate liquors may exert toxicity on nitrifying bacteria due to the high FA concentration (Cotman and Gotvajn, 2010). The inhibition thresholds for ammonia oxidizing bacteria (AOB) and nitrite oxidizing bacteria (NOB) have been reported in the range of 10-150 and 0.1-1.0 $\mathrm{g} \mathrm{N} / \mathrm{m}^{3}$, respectively (Turk and Mavinic, 1989). It was also stated by Anthonisen et al. (1976) that the AOB activity is inhibited at FA concentration of $8-120 \mathrm{mg} \mathrm{N} / \mathrm{L}$, while the inhibition of NOB is observed at an FA concentration of $0.08-0.82 \mathrm{mg}$ $\mathrm{N} / \mathrm{L}$. Furthermore, nitrobacter has been reported to be immediately inhibited (both growth and respiration processes) at FA concentrations greater than $1.0 \mathrm{mg} \mathrm{N} / \mathrm{L}$ (Jaroszynski, 2012). However, limited information is available on the inhibitory effect of the digestate liquors on the nitrification and adaptation of the activated sludge to the digestate liquors.

In this study, in order to conduct successful implementation of the activated sludge process for the pre-treatment of digestate liquors, the following investigations were carried out: 1) determination of the allowable load of the digestate liquors to prevent FA inhibition on nitrification, 2) evaluation of the adaptation of the activated sludge under different loads of the digestate liquors, 3) optimization of the operational conditions (e.g. type of the external carbon source) for nutrient removal from the digestate liquors and further recovery.

\section{MATERIALS AND METHODS}

The experiments were carried out in two stages, with regard to the determination of the activated sludge adaptation rate under different loads of the digestate liquors in the lab scale (first stage) and in the pilot scale (second stage). Before applying biological treatment, suspended solids were removed from digestate liquors by coagula- tion with ferric (III) chloride preceding sedimentation. The studied digestate liquors exhibited a high $\mathrm{NH}_{4}^{+}$variation $\left(300-1200 \mathrm{~g} \mathrm{~N} / \mathrm{m}^{3}\right)$ due to the different substrates for anaerobic digestion. In the lab-scale experiments, the dosing amount of the digestate liquors varied in the range of $5-10 \%$ of the reactor working volume to maintain a constant $\mathrm{NH}_{4}^{+}$concentration $(\approx 30 \mathrm{mg} \mathrm{N} / \mathrm{L})$. As far as the pilot-scale experiment is concerned, the dosing amount of the digestate liquors ranged from 5to $7.5 \%$ of the reactor working volume to maintain a constant $\mathrm{NH}_{4}^{+}$concentration $(\approx 15 \mathrm{mg} \mathrm{N} / \mathrm{L})$.

The lab-scale experiments were carried out during a period of 22 days in a plexiglass sequencing batch reactor (SBR) with a working volume of $10 \mathrm{~L}$ equipped with electrodes and probes (Endress+Hauser, Switzerland) for continuous monitoring of $\mathrm{pH}$ (CPS471D), temperature and dissolved oxygen (DO) (COS22D) (Figure 1a). The process temperature was kept constant at $25^{\circ} \mathrm{C}$. The SBR was inoculated with the activated sludge from the municipal wastewater treatment plant (WWTP) in Gdynia. The concentration of mixed liquor volatile suspended solids (MLVSS) varied in the range of $3.1-3.8 \mathrm{~kg} / \mathrm{m}^{3}$. A single operational cycle lasted for 12 hours and consisted of the nitrification phase (from $4 \mathrm{~h}$ to 5 $\mathrm{h}$ ), denitrification phase (from $7 \mathrm{~h}$ to $6 \mathrm{~h}$ ) as well as settling and decantation phase $(1 \mathrm{~h})$. The durations of the nitrification and denitrification phases were designed for the adaptation of the activated sludge under the increasing loads of the digestate liquors (increasing $\mathrm{NH}_{4}^{+}$concentrations) to ensure full nitrification. During the nitrification phase, the DO concentration was set above $2.0 \mathrm{~g}$ $\mathrm{O}_{2} / \mathrm{m}^{3}$ by using PI control system and the $\mathrm{pH}$ was controlled above 6.8 by automatic dosing sodium hydroxide $(\mathrm{NaOH})(6 \mathrm{~mole} / \mathrm{L})$. In the course of the denitrification phase, ethanol was added as the external carbon source $(6 \mathrm{~g} \mathrm{COD} / \mathrm{g} \mathrm{N})$. The concentrations of principal compounds, including total nitrogen $(\mathrm{TN}), \mathrm{NH}_{4}-\mathrm{N}$, nitrate $\left(\mathrm{NO}_{3}-\mathrm{N}\right)$, nitrite $\left(\mathrm{NO}_{2}-\mathrm{N}\right)$, total phosphorus (TP), phosphate $\left(\mathrm{PO}_{4}-\mathrm{P}\right)$ and chemical oxygen demand (COD), were analyzed once a week in the influent (fresh digestate liquors) and twice a week in the effluent (during the decantation phase) to control the process performance in the reactor. The ammonia uptake rate (AUR) and nitrate utilization rate (NUR) were determined once a week by analyzing the principal compounds each hour during the whole cycle. The concentrations of $\mathrm{NH}_{4}-\mathrm{N}, \mathrm{NO}_{3}-\mathrm{N}$, $\mathrm{NO}_{2}-\mathrm{N}, \mathrm{TP}, \mathrm{PO}_{4}-\mathrm{P}$ and $\mathrm{COD}$ were determined by using XION 500 spectrophotometer (Dr. Lange, 
$\mathrm{GmbH})$. TN was determined with TOC Analyzers - TNM-1 (Shimadzu, North America). The concentrations of MLVSS were determined by means of the gravimetric method, according to the Polish Standards (PN-72/C-04559).

The pilot-scale experiments were carried out during a period of 30 days in a pilot-scale SBR characterized by the working volume ranging from 0.25 to $0.50 \mathrm{~m}^{3}$ (with the drainage pipes fixed at different heights), equipped with the SC 1000 control module (Hach Lange, U.S.A) for continuous monitoring of DO (LDO LXV 416.99.0000.1), $\mathrm{NH}_{4}-\mathrm{N}$ and $\mathrm{NO}_{3}-\mathrm{N}$ (ANISE), $\mathrm{pH}$ control module (CPS model 11- 2BA2ESA, Endress + Hauser, Germany) for continuous monitoring of $\mathrm{pH}$ and the $\mathrm{pH}$ adjustment systems (Grundfos Alldos / DDI 222, Germany) (Figure 1b). The process temperature was kept constant at $20^{\circ} \mathrm{C}$. The reactor was inoculated with the activated sludge originating from Swarzewo WWTP. The MLVSS concentrations varied in the range of $4.5-4.8 \mathrm{~kg} / \mathrm{m}^{3}$. The operational parameters were set in accordance with those from the labscale SBR. Fossil oil was added as the external carbon source $(6 \mathrm{~g} \mathrm{COD} / \mathrm{g} \mathrm{N})$ during the denitrification phase. The AUR, NUR were determined once a week.

\section{RESULTS AND DISCUSSION}

Four typical samples are presented in Figure 2 , with regard to the beginning and end of the labscale (a-b) and pilot-scale (c-d) experiments. In the lab-scale experiments (Figure 2a-2b), a nearly constant $\mathrm{NH}_{4}^{+}$concentration $(\approx 30 \mathrm{mg} \mathrm{N} / \mathrm{L})$ was maintained by dosing the digestate liquors in the range of $5-10 \%$ of the reactor working volume.
A slower $\mathrm{NH}_{4}^{+}$consumption was observed over time (from $\mathrm{t}=0$ to $\mathrm{t}=22 \mathrm{~d}$ ), which indicated a potential inhibitory effect of the digestate liquors on the nitrifying bacteria. However, an apparent faster $\mathrm{NO}_{3}{ }^{-}$consumption was noted over time (from $\mathrm{t}=0$ to $\mathrm{t}=22 \mathrm{~d}$ ), indicating the adaptation of the activated sludge to the digestate liquors, especially for the heterotrophic biomass.

In the pilot-scale experiments (Figure 2c-2d), the dosing amount of the digestate liquors varied in the range of $5-7.5 \%$ of the reactor working volume to maintain a constant $\mathrm{NH}_{4}^{+}$concentration of $15 \mathrm{mg} \mathrm{N} / \mathrm{L}$. Different $\mathrm{NH}_{4}^{+}$consumption patterns were observed over time (from 0 to $30 \mathrm{~d}$ ). In the beginning $(\mathrm{t}=0 \mathrm{~d})$, the $\mathrm{NH}_{4}^{+}$consumption was faster during the first hour of the nitrification process and then slowed down until the reaction finished, showing a lag of the inhibitory effect on the nitrifying bacteria. Conversely, at the end $(t=30$ d), the $\mathrm{NH}_{4}^{+}$consumption showed a constant rate during the whole nitrification process, indicating a potential adaptation of the nitrifying bacteria to the toxicity. A slightly slower $\mathrm{NH}_{4}^{+}$consumption was noticed during the whole period (from $\mathrm{t}=0$ to $\mathrm{t}=30 \mathrm{~d}$ ) The $\mathrm{NO}_{3}{ }^{-}$consumption in the denitrification process was faster when $\mathrm{t}=30 \mathrm{~d}$, in comparison with $\mathrm{t}=0 \mathrm{~d}$.

For further investigations, AUR (a) and NUR (b) measurements during the lab- and pilot-scale experiments are presented in Figure 3. During the nitrification process (Figure 3a), the lab-scale AUR values gradually decreased from 5.3 to $2.6 \mathrm{~g}$ $\mathrm{N} /(\mathrm{kg}$ VSS $\cdot h)$ over time and finally remained stable around $2.6 \mathrm{~g} \mathrm{~N} /(\mathrm{kg} \mathrm{VSS} \cdot \mathrm{h})$, showing a clear inhibitory effect of the digestate liquors on the nitrification process. The trend was well described by the exponential function in Figure 3a. This negative effect was probably attributed to the rel-
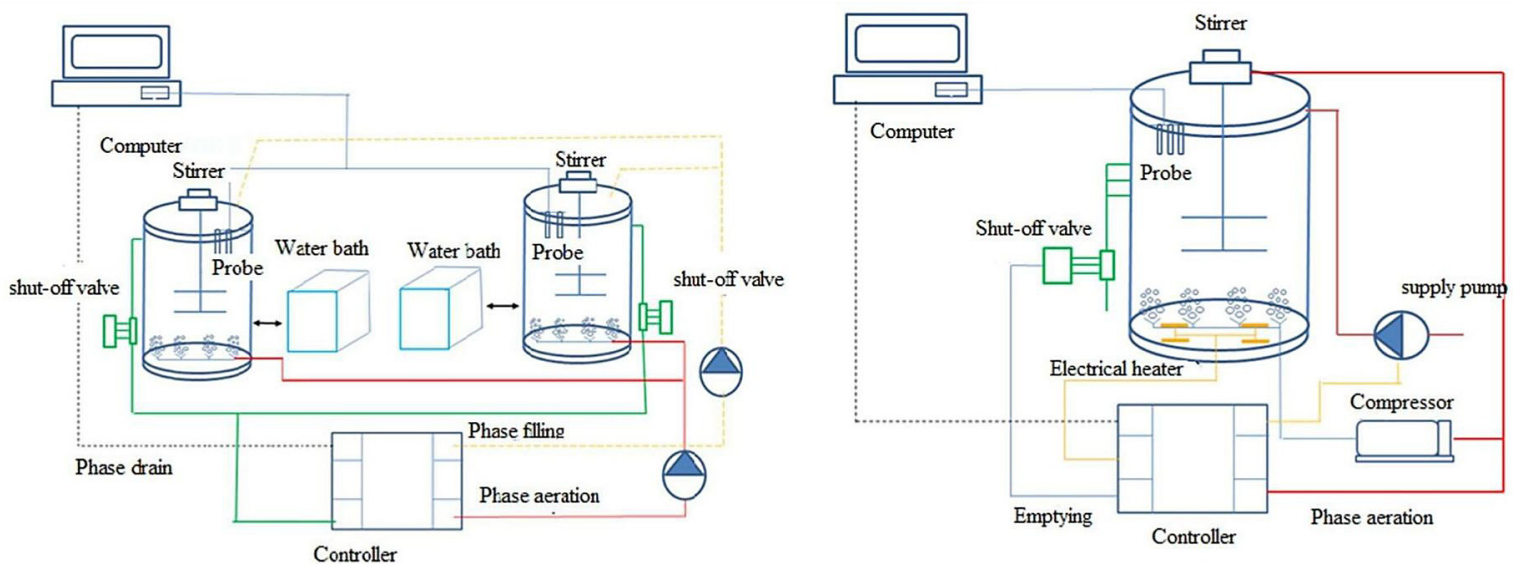

Figure 1. Schemes of the lab-scale SBR (a) and pilot-scale SBR (b) systems 
a) $t=0 d$

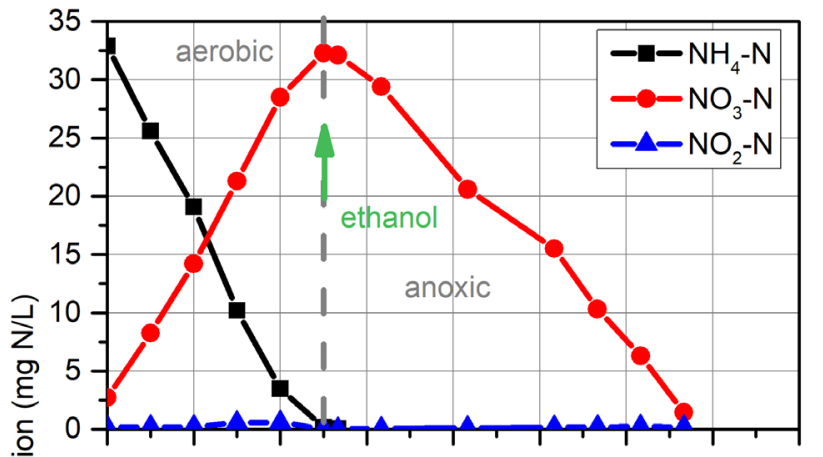

b) $t=22 d \quad$ Lab-scale $25^{\circ} \mathrm{C}$

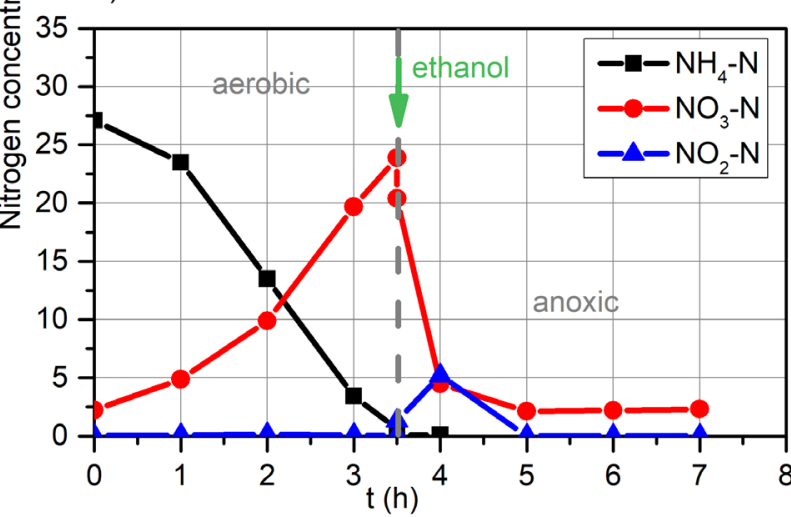

c) $t=0 d$

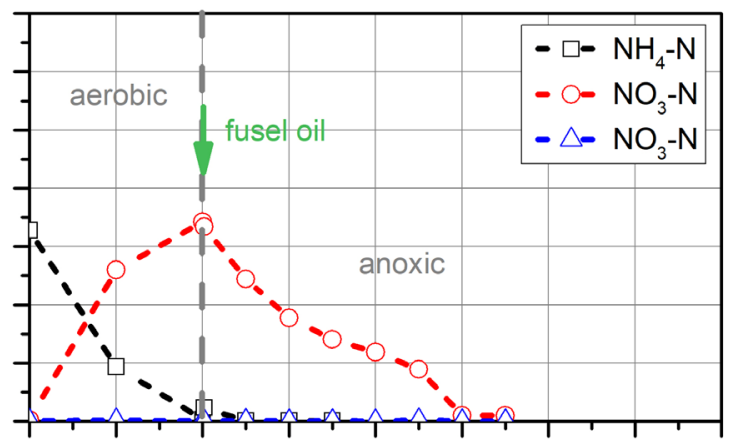

d) $t=30 d$

Pilot-scale $20^{\circ} \mathrm{C}$

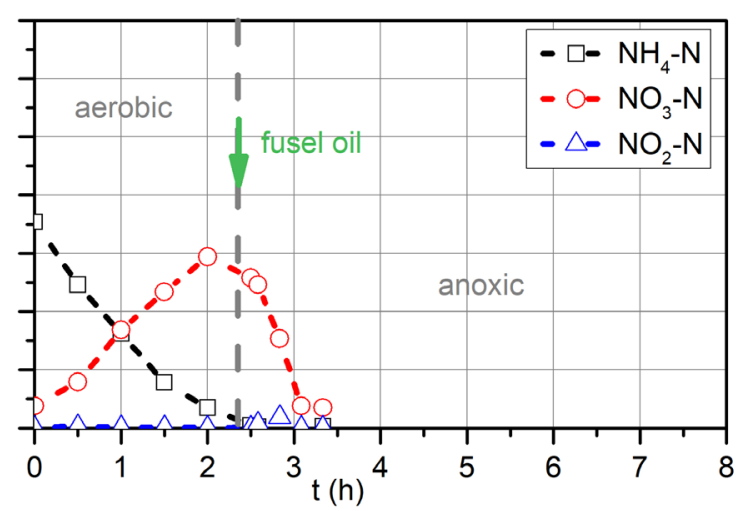

Figure 2. Nitrogen profiles during the lab-scale (a-b) and pilot-scale (c-d) experiments

a)

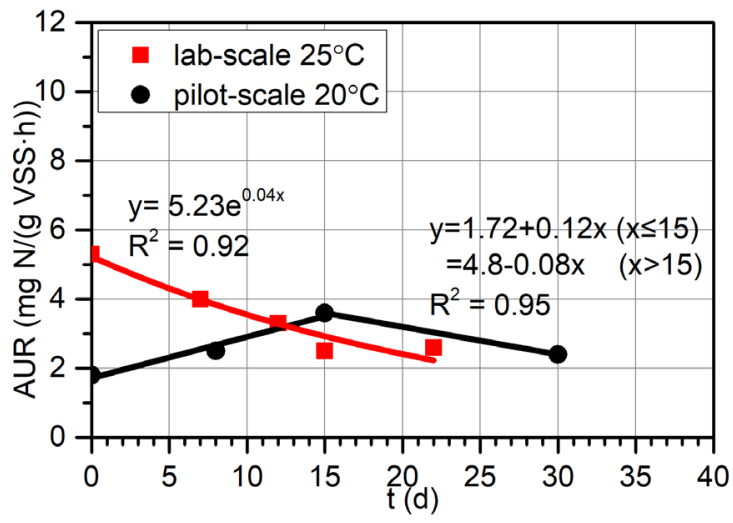

b)

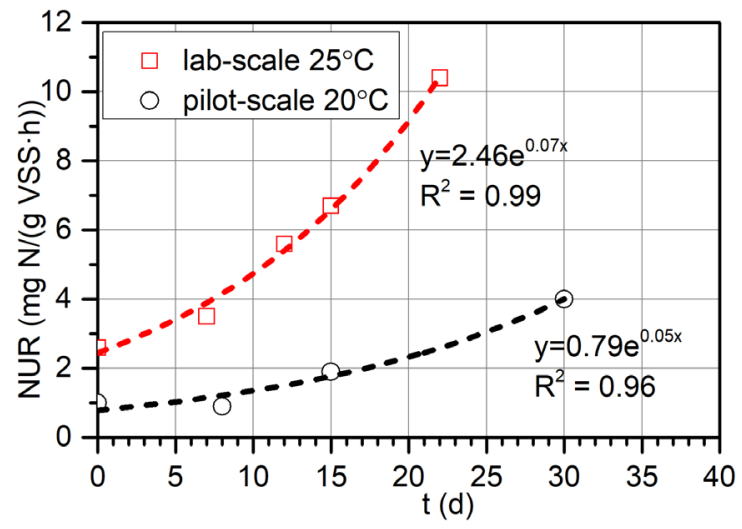

Figure 3. AUR (a) and NUR (b) measurements during the lab- and pilot-scale experiments

ative high FA concentration (0.3-0.5 $\mathrm{mg} \mathrm{N} / \mathrm{L})$, as Turk and Mavinic (1989) reported that FA inhibited the activity of $\mathrm{AOB}$ and $\mathrm{NOB}$ in the concentration range of $10-150$ and $0.1-1.0 \mathrm{~g} \mathrm{~N} / \mathrm{m}^{3}$, respectively. The pilot-scale AUR values increased from 1.8 to $3.6 \mathrm{~g} \mathrm{~N} /(\mathrm{kg} \mathrm{VSS} \cdot \mathrm{h})$ in the first two weeks and then decreased to $2.4 \mathrm{~g} \mathrm{~N} /(\mathrm{kg} \mathrm{VSS} \cdot \mathrm{h})$. This observation could be well described by the linear equation groups in Figure 3a. It indicated the lag of the inhibitory effect of the studied digestate liquor on the nitrifying bacteria at the relatively low FA concentration $\approx 0.15 \mathrm{mg} \mathrm{N} / \mathrm{L}$. The apparent lag time of the FA inhibition showed a bacterial resistance to the toxicity. In comparison, similar AUR ranges were also reported by Bernat et al. (2011) and Zhu et al. (2013), i.e. 1.73-4.6 $\mathrm{g} \mathrm{N} /(\mathrm{kg} \mathrm{VSS} \cdot \mathrm{h})$ for the treatment of a mixture of wastewater and anaerobic sludge digester supernatant in an SBR at limited oxygen concentration (DO $<0.7 \mathrm{mg} \mathrm{O}_{2} / \mathrm{L}$ ) and $7.43 \mathrm{~g} \mathrm{~N} /(\mathrm{kg} \mathrm{VSS} \cdot \mathrm{h}$ ) for the treatment of the diluted landfill leachate in a post-denitrification SBR.

During the denitrification process (Figure $3 b)$, the lab-scale NURs increased from 2.6 to $10.4 \mathrm{~g} \mathrm{~N} /(\mathrm{kg} \mathrm{VSS} \cdot \mathrm{h})$ over time. A similar trend was also observed in the pilot-scale NURs, i.e. 
from 1.0 to $4.0 \mathrm{~g} \mathrm{~N} /(\mathrm{kg} \mathrm{VSS} \cdot \mathrm{h})$. Both trends could be well described with the exponential functions, as shown in Figure 2b. During both the lab- and pilot-scale experiments, the shortening of the denitrification phases over time corresponded well to the increase in the NURs. A similar trend was also reported by Czerwionka et al. (2014), i.e. the NURs increased continuously from below 1 to $10 \mathrm{~g} \mathrm{~N} /(\mathrm{kg} \mathrm{VSS} \cdot \mathrm{h})$ under ethanol substrate with the increase in the volumetric addition of sludge digester liquors over time. A similar value was also reported by Gong et al. (2013), i.e. $5.16 \mathrm{~g}$ $\mathrm{N} /(\mathrm{kg}$ VSS $\cdot \mathrm{h})$ under acetate substrate at $22{ }^{\circ} \mathrm{C}$. Furthermore, both observations with the lag in the beginning of the experimental period showed the adaptation of the heterotrophic biomass to the digestate liquors. The differences between the lab scale and pilot scale could partially be attributed to the type of the external carbon sources (ethanol vs. fusel oil) applied to support the denitrification process at slightly different temperatures (25 vs. $20^{\circ} \mathrm{C}$ ). It indicated that at a slightly higher temperature, ethanol served as a more efficient external carbon source for the adaptation of the activated sludge. The efficiencies of nitrogen removal during the lab and pilot-scale experiments were similar and ranged from 88 to $93 \%$.

\section{CONCLUSIONS}

A lag of the inhibition of the digestate liquors on the nitrification process was observed, indicating the resistance of the nitrifying bacteria to the FA toxicity. Even though a relatively high FA concentration (0.3-0.5 mg N/L) showed a clear inhibitory effect on nitrification, a potential adaptation of the nitrifying bacteria to the FA inhibition was also observed at a relatively low FA concentration $(0.15 \mathrm{mg} \mathrm{N} / \mathrm{L})$. The adaptation of the heterotrophic biomass to the digestate liquors was observed both in the lab-and pilot-scale experiments. The relatively higher NUR values in the lab scale indicated that at a slightly higher temperature, ethanol served as a more efficient external carbon source for better adaptation of the biomass under unfavorable conditions. In comparison with the denitrification process, greater attention had to be paid to the nitrification process for stable maintenance, as the latter process was more vulnerable to the toxicity. The activated sludge process, technically feasible and economically efficient for nutrient removal under unfavor- able conditions, proved to be a promising alternative for the pre-treatment of the digestate liquors.

\section{Acknowledgments}

This study was financially supported by Norwegian funds Program implemented by the National Center for Research and Development (implementation period 2013-2016), within the framework of the Polish-Norwegian Research Cooperation under research project No. Pol-Nor / 202919/57/2013 Pomeranian Biogas Model.

\section{REFERENCES}

1. Anthonisen, A.C., Loehr, R.C., Prakasam, T.B.S., Srinath, E.G., 1976. Inhibition of Nitrification by Ammonia and Nitrous Acid. J. (Water Pollut. Control Fed. 48, 835-852.

2. Bernat, K., Kulikowska, D., Zielińska, M., CydzikKwiatkowska, A., Wojnowska-Baryła, I., 2011. Nitrogen removal from wastewater with a low $\mathrm{COD} / \mathrm{N}$ ratio at a low oxygen concentration. Bioresour. Technol. 102, 4913-4916. doi:10.1016/j. biortech.2010.12.116

3. Cotman, M., Gotvajn, A.Ž., 2010. Comparison of different physico-chemical methods for the removal of toxicants from landfill leachate. J. Hazard. Mater. 178, 298-305. doi:10.1016/j. jhazmat.2010.01.078

4. Czerwionka, K., Luczkiewicz, A., Majtacz, J., Kowal, P., Jankowska, K., Ciesielski, S., Pagilla, K., Makinia, J., 2014. Acclimation of denitrifying activated sludge to a single vs. complex external carbon source during a start-up of sequencing batch reactors treating ammonium-rich anaerobic sludge digester liquors. Biodegradation 25, 881892. doi:10.1007/s10532-014-9707-0

5. Daigger G. T. 2014. Ardern and Lockett remembrance. W: Jenkins D., Wanner J. (edit.) Activated sludge - 100 years and counting (p. 1-15). London. IWA Publishing.

6. Gong, L., Huo, M., Yang, Q., Li, J., Ma, B., Zhu, R., Wang, S., Peng, Y., 2013. Performance of heterotrophic partial denitrification under feast-famine condition of electron donor: A case study using acetate as external carbon source. Bioresour. Technol. 133, 263-269. doi:10.1016/j.biortech.2012.12.108

7. Holm-Nielsen, J.B., Al Seadi, T., Oleskowicz-Popiel, P., 2009. The future of anaerobic digestion and biogas utilization. Bioresour. Technol. 100, 54785484. doi:10.1016/j.biortech.2008.12.046

8. Jaroszynski, L.W., 2012. The Influence of Nitrite and Free Ammonia on Nitrogen Removal Rates in 
Anoxic Ammonium Oxidation Reactors.

9. Møller, H.B., Nielsen, A.M., Andersen, G.H., Nakakubo, R., 2006. Process performance of biogas plants integrating pre-separation of manure, in: 12th Ramiran International Conference.

10. Onay, T.T., Pohland, F.G., 1998. In situ nitrogen management in controlled bioreactor landfills. Water Res. 32, 1383-1392. doi:10.1016/ S0043-1354(97)00392-8
11. Turk O., Mavinic D.S., 1989. Stability of nitrite build-up in an activated sludge system. J.W.P.C.F. $61,1440-1448$.

12. Zhu, R. long, Wang, S. ying, Li, J., Wang, K., Miao, L., Ma, B., Gong, L. xiao, Peng, Y. zhen, 2013. Effect of influent $\mathrm{C} / \mathrm{N}$ ratio on nitrogen removal using $\mathrm{PHB}$ as electron donor in a post-denitritation SBR. J. Chem. Technol. Biotechnol. 88, 1898-1905. doi:10.1002/jctb.4047 